\title{
Financial market regulation, country governance, and bank efficiency: Evidence from East Asian countries
}

\author{
Sok-Gee Chan ${ }^{1}$, Mohd. Zaini Abd. Karim²
}

\begin{abstract}
This paper examines the relationship between financial market regulation, country governance and efficiency of commercial banks in East Asian economies during the period 2001-2008 using a twostage estimation technique. In the first stage, we employ a non-parametric approach—Data Envelopment Analysis (DEA) — to estimate the banks' cost and profit efficiency scores and then Tobit estimation to analyze the impact of financial market regulations and country governance on bank efficiency. The results suggest that commercial banks in East Asia are relatively profit efficient rather than cost efficient. The findings show that countries with more financial freedom and independence are more cost efficient. Moreover, government effectiveness is found to be positively related to bank efficiency. Consistent with economic theory, corruption is negatively related to bank efficiency. Therefore, this study reveals the importance of financial market regulations and country governance as catalysts for efficient banking operations in East Asian economies.
\end{abstract}

KEY WORDS: $\quad$ bank efficiency; institutional environment; data envelopment analysis; tobit regression; East Asia

JEL Classification: $\quad$ G21; G28; D24

'Department of Finance and Banking, Faculty of Business and Accountancy, Universiti of Malaya, Malaysia

${ }^{2}$ Othman Yeop Abdullah Graduate School of Business, Universiti Utara Malaysia, Malaysia

\section{Introduction}

The importance of banks in an economy is undeniable because they serve as the main sources of business financing. An effective and efficient banking system contributes to the effectiveness of monetary policy transmission in developing economies because they rely heavily on bank-based activities due to their underdeveloped capital markets. As a result, the banking system in most developing countries,

Correspondence concerning this article should be addressed to: Sok-Gee Chan, Department of Finance and Banking, Faculty of Business and Accountancy, Universiti of Malaya, 50603 Kuala Lumpur.Tel: 03-79673888 fax:03-79673980 E-mail: sokgee@um.edu.my including East Asian economies, is highly regulated, with the primary objective of establishing a sound and resilient financial system.

According to Mishkin (2000), prudent regulation of the banking industry stems from concerns over issues such as regulation of competition, disclosure requirements, examining and monitoring procedures and restrictions in banking activities, including limitation of asset holdings, capital requirements and separation of banking and other financial activities. Previous studies by Stigler (1971), Johnson, Kaufmann and Shelifer (1997), Besley and Burgess (2004) and Asaftei and Kumbhakar (2008) recognize the importance of government regulations to protect and enhance the 
growth of the banking system. Banking regulations aim primarily to reduce banks' exposure to risky assets and thus protect stakeholders from financial runs. Beltratti and Stulz (2009) note that lax regulation could contribute to excessive risk-taking by banks.

Giannone, Lenza and Reichlin (2010) argue that regulation of banking competition is necessary, especially in developing countries because of the increase in the openness of financial markets that could result in higher banking costs. This issue is still open to debate because economic theory presumes that an increase in competition actually fosters efficiency in the banking system as banks tend to find ways of lowering production costs to ensure their long-term survival (Barth, Caprio, \& Levine, 2004; Chan \& Karim, 2010; Claessens \& Laeven, 2004). On the other hand, overly stringent regulation of financial markets might damage banks' performance by preventing them from exploiting economies of scale and scope through a more diversified range of banking products or a larger scale of operations (Barth, Brunmgaugh, \& Wilcox, 2000; Barth et al., 2010; Claessens \& Klingebiel, 2001). In this context, regulations could lead to an inefficient allocation of resources; in contrast, deregulation enables and encourages banks to take advantage of more efficient production techniques (Evanoff, 1998).

Looking at institutional environments enables us to take into account the quality of a country's governance in affecting the performance of the banking sector. An appropriate legal framework and institutional environment contribute to a country's market development and financial development (Claessens \& Laeven, 2004; Demirgüc-Kunt, Laeven, \& Levine, 2004). A strong legal framework is crucial for the development of a mature financial system (Beck et al., 2001). Nabi and Suliman (2008) stress the contribution of a legal framework in strengthening banking system, whereas González (2009) argues that a well-functioning market depends on contracts and legal enforceability. Hence, this paper aims to examine the relationship between financial market regulation, institutional environment and efficiency of commercial banks in East Asian economies for the period 2001-2008. In particular, we study the effect of tight banking regulation and countries' governance on bank efficiency.

This paper's contribution to the literature is twofold. First, this is the first study conducted on the Asian region regarding the impact of financial market regulations and institutional environment on bank efficiency. Because the debate about the effects of regulations on banks' performance has been inconclusive to date, this study will further focus on financial market regulations in terms of bank ownership, competition, financial development, banking freedom and monetary policy to determine their effects on both banks' cost and profit efficiency. Second, this paper contributes to the scarce line of literature on the impact of regulation and country governance on bank efficiency.

The rest of the paper is organized as follows. Section 2 provides an overview of financial market regulations and institutional environment in the East Asian region. Section 3 reviews the related literature. Section 4 describes the methodology and data employed in the study. Section 5 presents the results and discusses the findings. Finally, section 6 concludes the paper.

\section{Financial market regulations and country governance in the East Asian region}

East Asia-with rapidly growing economies-is one of the most dynamic and important regions in the world. Furthermore, it comprises the second largest economy of China and Japan as the third largest economy in the world. The East Asian financial sector is dominated by commercial banks, which account for up to $80 \%$ of the sector. According to many analysts, these banks were considered the heart of the problems leading to the Asian crisis in 1997. Hence, to provide an indication of the competitiveness and openness of this region's banking sector, we look at four specific indicators from the Economic Freedom Network developed by Gwartney, Lawson and Hall (2011), namely, ownership of banks, foreign bank competition, private sector credit and interest rate controls. The index ranges between " 0 " and " 10 ", with higher ratings assigned to countries with more economic freedom.

Bank ownership is computed based on the percentage of deposits that are privately held by the banks (Gwartney et al., 2011), where a high rating is assigned to countries with large shares of privately held deposits. Table 1 shows that the banking industry in Hong Kong is relatively more competitive than that in the other countries in the region (privately held deposits 
Table 1. Indicators of financial market regulation and country governance in East Asian economy, 2001-2008

\begin{tabular}{lcccccccc}
\hline & \multicolumn{3}{c}{ Financial Market Regulation } & \multicolumn{3}{c}{ Country Governance } \\
\hline Country & $\begin{array}{c}\text { Ownership of } \\
\text { banks }\end{array}$ & $\begin{array}{c}\text { Competition } \\
\text { in domestic } \\
\text { banking }\end{array}$ & $\begin{array}{c}\text { Interest rate } \\
\text { regulations }\end{array}$ & $\begin{array}{c}\text { Credit } \\
\text { Market } \\
\text { Regulation }\end{array}$ & $\begin{array}{c}\text { Political } \\
\text { Stability }\end{array}$ & $\begin{array}{c}\text { Government } \\
\text { Effectiveness }\end{array}$ & $\begin{array}{c}\text { Regulatory } \\
\text { Quality }\end{array}$ & $\begin{array}{c}\text { Control for } \\
\text { corruption }\end{array}$ \\
\hline China & 1.00 & 5.15 & 9.75 & 6.01 & -0.24 & 0.02 & -0.33 & -0.49 \\
Hong Kong & 10.00 & 7.91 & 10.00 & 9.07 & 1.00 & 1.57 & 1.81 & 1.58 \\
Japan & 6.50 & 7.52 & 10.00 & 8.18 & 1.09 & 1.29 & 1.00 & 1.18 \\
Korea & 6.50 & 7.90 & 10.00 & 8.25 & 0.36 & 1.07 & 0.75 & 0.44 \\
Taiwan & 5.00 & 6.78 & 10.00 & 7.84 & 0.41 & 1.10 & 1.02 & 0.73 \\
\hline
\end{tabular}

Source: Financial market regulation indicators are obtained from Economic Freedom Network by Gwartney et al. (2011), whereas the country governance indicators are from Kaufmann et al. (2009)

have a rating of 10). The rating indicates that private deposits dominated the deposits from government agencies by 95 to $100 \%$. On the other hand, China is still relatively stringent in its banking operations, with an average bank ownership rating of 1 . Privately held deposits only constitute between 10 and $40 \%$ of banking assets.

On the other hand, the foreign bank competition index is used to capture the existence of foreign banks in a country's banking industry. This index is calculated based on approved foreign bank applications and foreign banking assets in the country's overall banking sector (Gwartney et al., 2011). Table 1 shows that the index for foreign bank competition on average ranges between 5.15 and 7.91. This finding indicates that the region's economies are still relatively closed to foreign bank participation because foreign bank assets are less than $79 \%$, with license approvals of less than $50 \%$ from the overall banking industry. However, the financial markets in East Asia are relatively open because most of the countries exhibit high scores in terms of interest rate regulations. This openness is observed because countries with interest rates determined by market forces, stable monetary policy and positive real deposit and lending rates are assigned higher interest rate regulation ratings (Gwartney et al., 2011). On average, most of the countries, except for China, score an average of 10 in interest rate controls-which means that interest rates are primarily allowed to float in line with market forces with reasonable deposit and lending rate spreads as well as with positive real interest rates, as suggested by Gwartney et al. (2011).

Overall, the credit market regulation in East Asia is above average, with an index of between 6.01 and 9.07. Credit market regulation reflects the overall banking industry operation in a country, which includes the country's openness to foreign banking activities, freedom from government control and freedom for interest rates to be determined by market forces. In this case, Hong Kong has an average index of 9.07, which is the highest among all the countries. This high index may be observed because Hong Kong-with its relatively open and well-developed financial market-is the main financial hub in Asia. On the other hand, China's credit market regulation reported an average index of 6.01, which can be attributed to more stringent restrictions in terms of foreign bank participation compared with those instituted in the other countries examined in this study.

The country governance indicators are used to represent the selection, monitoring and replacement process of a government. The indicators also include the effectiveness of government policy implementation and formulation as well as the freedom of the country's citizens in expressing their voices. The governance indicators of Kaufmann, Kray and Mastruzzi (2009) follow a normal distribution, with scores lying between -2.5 and 2.5 , where high scores represent favorable outcomes. The four indicators used in measuring a country's governance are political stability and absence of violence; government effectiveness; regulatory quality and control of corruption. 
Table 1 shows that China, on average, has a weaker governance than the other countries in the region. Moreover, the index of control of corruption in China is relatively low compared with that of the other countries selected for this study. This situation may result in an inefficient banking and financial market in China because both public and private institutions exercise their power for private gain. In addition, China is rated below average in terms of regulatory quality, with an average of -0.33 . This score indicates that the Chinese government is weak in promoting the development of the private sector. On the other hand, Hong Kong has better governance than other countries, which reflects its status as one of the developed countries in the region. Hong Kong's relatively greater financial openness has helped the island become the region's financial center.

\section{Literature review}

Studies on environmental factors that affect bank efficiency levels are important for predicting the effects of country variables and regulatory changes on bank performance (Chan \& Karim, 2010). Dietsch and Lozano-Vivas (2000) noted that the inclusion of country environmental factors is important in cross-country analyses of bank efficiency. This notion is supported by Beltratti and Stulz (2009), who argued that differences in the regulation of financial institutions are useful in explaining banks' performance, especially during banking crises.

Many economists believe that a free market enhances the efficiency level of firms by allowing for healthy competition (Claessens \& Laeven, 2004; Evanoff, 1998). Banks are able to exploit economies of scale and alter their production technology given the country's financial freedom (Evanoff, 1998). Evanoff found that heavy regulation damaged US banks' efficiency level from 1972 to 1987 . This finding is supported by Claessens and Klingebiel (2001), who found that greater flexibility in banking operations enabled banks to exploit economies of scale and scope. The authors also found that restrictions in banking activities increased the likelihood that banks would suffer during banking crises. Barth et al. (2004) also found that greater regulatory restrictions resulted in a higher probability of banks to suffer during banking crises and that there was a negative relationship between banking restrictions and banking sector development and stability.
Similarly, González (2005) found that stricter regulations lead to higher risk-taking incentives by banking institutions, leading to a reduction in charter value and stability of the banking system.

Claessens and Laeven (2004) examined the effects of entry and regulations on banking activities in 50 countries for the period 1994-2001. They found that the entrance of foreign banks and a decrease in restrictions on banking activities resulted in higher competitiveness. The results also suggest that such factors contribute to higher contestability of the banking sectors and eventually help create healthy competition. Barth et al. (2004) also found that tighter entry restrictions limited banking contestability and competition and led to lower banking efficiency. These results are supported by Barth et al. (2010) in their analysis of bank efficiency in 72 countries for the period 1999-2007. They found that tighter regulations reduced bank efficiency. They also found that greater independence of supervisory authority enhanced bank efficiency level.

However, studies on the effect of regulation on banking performance have not yet reached a consensus. Kalish and Gilbert (1973), in examining the influence of bank regulations in the US, found that regulatory decisions failed to explain the efficiency level of banks. Demirguc-Kunt et al. (2004) also found that bank regulations appear to be insignificant in explaining the profitability and banking costs of commercial banks. Pasiouras (2008), in his analysis of the impact of regulations on banks' technical efficiency in 95 countries, found no significant relationship between restrictions on bank activities and efficiency levels.

On the other hand, González (2009) found that restrictions on bank activities by means of market monitoring and better contracting led to an increase in bank efficiency. Demirguc-Kunt et al. (2004) also found that stricter bank entry requirements and tighter banking activities contributed to higher net interest margins in the banking system. This finding is supported by Lensink, Meesters and Naaborg (2008), who found that an increase in foreign bank ownership correlated negatively with bank efficiency. González (2009) also found that stricter bank regulations reduced banking risk in poorly developed financial markets. This result was confirmed by Delis, Molyneux and Pasiouras (2009), who found that banking restrictions in 22 transition countries contributed to higher bank productivity. Beltratti and Stulz 
(2009) also argued that banks performed better under stronger capital supervision and restrictions.

Political stability, government effectiveness, regulatory quality and control of corruption are also important for banking activities. However, studies on the effects of such factors on bank efficiency are limited. Demirguc-Kunt et al. (2004) examined the regulations, market structure, institutions and the cost of financial intermediation in 72 countries. They found that financial intermediation cost was lower in countries with better property rights, stronger contract enforcement and a higher level of judicial efficiency. The authors stressed that such factors help to increase the collateral value of bank loans. This finding is consistent with the results of La Porta et al. (1998) and Jappelli and Pagano (2002), who found that good judiciary and legal enforcement contributed to lower credit risk in banking institutions.

Lensink and Meesters (2007) studied the effect of institutional differences on the operating efficiency of commercial banks. They found that better institutions can improve banks' efficiency. They also found that banks in countries with a better institutional environment used technologies more efficiently and hence lowered the cost of operations. Chen (2009) found that commercial banks in 10 Sub-Saharan African countries exhibited higher efficiency scores under more stable economic conditions. This result suggests that stronger legal rights, enforcement of contracts, political stability and government effectiveness contribute positively to bank efficiency.

Al-Obaidan (2009) also examined the impact of monetary stability on commercial banks' technical and scale efficiency in six Gulf Cooperation Council (GCC) emerging economies. He found that higher monetary stability resulted in higher scale efficiency. The result also suggests that the technical efficiency of the commercial banking industry in GCC countries is influenced by monetary stability scores.

Sufian and Habibullah (2010) studied the relationship between institutional environment and bank performance for commercial banks in Malaysia. Using data for both foreign and locally owned commercial banks in Malaysia from 1999 to 2007, the authors found that economic freedom, business freedom, financial freedom and freedom from corruption correlated positively with banks' profitability. However, monetary freedom correlated negatively with banks' profitability, which indicates the importance of the government's role in controlling monetary policy.

However, studies on the effect of institutional factors on bank performance have failed to reach a consensus. Studies by Engerman and Sokoloff (1997), Acemoglu, Johnson and Robinson (2001) and William and Levine (2003) show that better institutional environment resulted in lower bank earnings. However, Borovicka (2007) failed to find any significant relationship between indexes of economic freedom and banking costs in 19 transition economies. He also found that the index concerning banking sector reforms correlated positively with the total costs of the banks, which suggests that banking sector reforms resulted in higher banking costs.

Based on the existing literature, there is to date no consensus regarding the effects of banking regulations and institutional environment on banks' performance. This lack of consensus may persist because most studies have failed to consider the governance setup in the countries under investigation. Researchers may omit governance setup because a country's institutional framework, such as economic freedom and country governance, are better able to reflect true market behavior (Claessens \& Laeven, 2003). Hence, according to the theory of industrial organization, it is crucial to consider a country's institutional framework when analyzing firms' performance.

This study will go further by analyzing the effects of financial market regulations and country governance on banks' efficiency. In addition, the studies mentioned above were mostly conducted on developed economies, especially European countries, using cross-country analyses characterized by different regulatory frameworks, thus making it important to control for country governance. Moreover, the results obtained from developed markets and European markets may not be applicable to Asian countries, where the respective banking industries are still highly regulated compared with the developed markets.

\section{Methodology and data}

\section{Methodology}

This study employed Data Envelopment Analysis (DEA) to estimate the cost and profit efficiency scores. The efficiency scores were then used in the second stage of the 
study to determine the effects of financial market regulations and country governance on bank efficiency in the selected East Asian countries. DEA is a linear programming approach first initiated by Farrell (1957) and further developed by Charnes, Cooper and Rhodes (1978) based on the concept of Pareto efficiency, whereby the production frontier is constructed using a set of efficient observations. A bank is considered to be Pareto efficient when it is unable to increase any output or reduce input combination without reducing other outputs or increasing the input being utilized in the production process (Chen \& Yeh, 2000). DEA is used to empirically measure the relative efficiency of a set of Decision Making Units (DMUs) leading to efficient firms on the frontier.

DEA is a well-known technique for measuring bank efficiency. The method generates efficiency estimates for firms with multiple inputs and outputs. DEA requires no a priori specification of functional forms, unlike the parametric method, and hence does not suffer from independent and identically distributed (iid) problems in the second-stage regression estimation. Furthermore, DEA performs relatively well with a small number of observations. Hence, this method was chosen to estimate cost and profit efficiency scores.

The cost efficiency concept based on DEA estimation is defined as the ability of banks to minimize cost in terms of technical and allocative efficiency. Technical efficiency refers to banks' ability to minimize an input mix given the level of outputs or maximize the output level when a fixed amount of input combination is given. On the other hand, allocative efficiency is defined as the ability of banks to optimally allocate their input mix given the prices of the inputs. Hence, the input price information is an important component in the estimation of cost efficiency.

The cost efficiency for $N$ firms $(\mathrm{i}=1, \ldots, \mathrm{N})$ is defined as the objective of the firms seeking to minimize cost by using a vector of $p$ inputs $x_{i}=\left(x_{i 1}, \ldots, x_{i p}\right) \notin \Re_{p++}$ given the price of inputs $w_{i}=\left(w_{i 1}, \ldots, w_{i p}\right) \notin \Re_{p++}$ to produce a vector of $q$ outputs $y_{i}=\left(y_{i 1}, \ldots, y_{i q}\right) \notin \Re_{q++}$. Therefore, the cost efficiency for the $j$ th firm can be estimated using Equation (1):

$$
\begin{aligned}
& \operatorname{Min} \sum_{p} w_{p j} x_{p j} \\
& \text { s.t. } \sum_{i} \lambda_{i} y_{i q} \geq y_{j q} \forall q \\
& \sum_{i} \lambda_{i} x_{i p} \leq x_{j p} \forall p \\
& \sum_{i} \lambda_{i}=1 ; \lambda_{i} \geq 0 ; \mathrm{i}=1, \ldots, \mathrm{N}
\end{aligned}
$$

The cost efficiency for the $j$ th bank is given by the ratio of minimum costs to actual costs and can be estimated using Equation 2:

$0 \leq C E_{j}=\frac{\sum_{p} w_{p j} X_{p j}^{*}}{\sum_{p} w_{p j} X_{p j}} \leq 1$

Profit efficiency measures banks' performances in terms of profit maximization. It is more widely acceptable as an economic concept than cost efficiency because it is conceptually broader and combines both the cost and revenue sides in estimating efficiency (Berger \& Mester, 1997). The profit function can be further categorized into standard and alternative profit functions to represent the degree of competitiveness in the market. The standard profit function assumes perfect competition in both the input and output markets, whereas the alternative profit function gives banks some control over the prices of outputs. According to Humphrey and Pulley (1997), the alternative profit function is better than the standard profit function in estimating banks' efficiency level because, in practice, banks are able to use their local market power in terms of deposit taking and granting loan, hence giving them some control in setting the prices of deposits and loans. Banks can also differentiate their financial products according to their targeted customers, geographical area and time. Therefore, we estimated profit efficiency using the alternative profit function.

The alternative profit efficiency for the $j$ th bank can be expressed as follows:

$$
\begin{aligned}
& \operatorname{Max} R_{j}-\sum_{p} w_{j p} x_{j p} \\
& \text { s.t. } \sum_{i} \lambda_{i} R_{i} \geq R_{j} \\
& \sum_{i} \lambda_{i} y_{i q} \geq y_{j q} \forall q \\
& \sum_{i} \lambda_{i} x_{i p} \leq x_{j p} \forall p \\
& \sum_{i} \lambda_{i}=1 ; \lambda_{i} \geq 0 ; \mathrm{i}=1, \ldots, \mathrm{N}
\end{aligned}
$$

where $R$ is the revenue of firm $j$. The alternative profit for the $j$ th bank is given by

$$
0 \leq A P E_{i}=\frac{R_{j}-\sum_{p} w_{j p} X_{j p}}{R_{j}^{*}-\sum_{p} w_{j p} X_{j p}^{*}} \leq 1
$$


The variable return to scale (VRS) obtained by setting $\sum \lambda_{i}=1$ is used in the estimation of both cost and profit efficiency. This approach is used because in practice, banks may not be able to proportionally increase both inputs and outputs simultaneously to be cost and profit efficient.

In the second stage of the analysis, Tobit regression estimation was used to determine the effect of capital market regulations and country governance on banks' cost and profit efficiency. The Tobit regression was estimated based on Equation (5).

$$
\begin{aligned}
E f f_{i t}= & \alpha_{i t}+\beta_{1} O W N_{i t}+\beta_{2} C O M_{j t}+\beta_{3} F D_{j t}+\beta_{4} M P_{j t}+\beta_{5} P S_{j t} \\
& +\beta_{6} G E_{j t}+\beta_{7} R Q_{j t}+\beta_{8} C C_{j t}+\beta_{9} S I Z E_{i t}+\varepsilon_{i t}
\end{aligned}
$$

where

Eff $_{\text {it }} \quad=$ average cost or profit efficiency scores of bank $i$ at time $t$ ( $\mathrm{t}=$ year of study)

$O W N_{i t}=$ ownership of bank $i$ at time $t$

$C O M_{j t}=$ foreign bank competition in country $j$ at time $t$

$F D_{j t} \quad=$ private sector credit in country $j$ at time $t$

$M P_{j t} \quad=$ interest rate control in country $j$ at time $t$

$P S_{j t} \quad=$ political stability in country $j$ at time $t$

$G E_{j t} \quad=$ government effectiveness in country $j$ at time $t$

$R Q_{j t} \quad=$ regulatory quality in country $j$ at time $t$

$C C_{j t}=$ control for corruption in country $j$ at time $t$

$S I Z E_{i t}=$ bank size (natural logarithm of total assets)

for bank $i$ at time $t$

$\varepsilon_{i t} \quad=$ error terms for bank $i$ at time $t$

Tobit regression analysis was used in this study because of the nature of the dependent variable and given that the efficiency scores are truncated between values of "0" and " 1 ". The ordinary least squares estimators of linear models will be biased and inconsistent in censored data. The Tobit regression was hence suggested to overcome the censored data by Tobin (1958). Nevertheless, Amemiya (1973) noted that the Tobit estimator is biased and inconsistent with the presence of heteroscedasticity and distributional misspecification. Therefore, we estimated the Tobit regression by adjusting for robust standard errors and by using the bootstrap-based approach based on 50 replications for a further robustness check of the model estimation. This method was suggested by Chortareas, Girardone, \& Ventouri (2013) because it incorporates the parametric structure and distributional assumptions of the equations. Tobit regression analysis has been widely used in the second-stage estimation of bank efficiency analysis based on the DEA approach (Isik and Hassan, 2003; Sufian and Habibullah, 2010).

\section{Data and definition of variables}

The sample examined in this study consists of selected commercial banks in the East Asian region, namely, China, Hong Kong, Japan, Korea, and Taiwan, for the period 2001-2008. The input and output specifications are based on the value-added approach proposed by Berger and Humphrey (1992), with the assumption that banks mostly perform typical businesses in a services industry. This approach considers all assets and liabilities as outputs when it contributes to the bank value added. Berger and Humphrey (1992) indicate that because banks pay out interest to depositors, the deposits are treated as outputs whereas the interest rate is considered the input price in generating the stated outputs. The financial products offered by commercial banks-loans, investment and deposits-are used as the banks' output vector. Hence, the input vectors used in producing the financial products and services are personnel costs, capital cost and cost of loanable funds. In this context, the price of labor was calculated by dividing the total personnel costs by total assets. The price of capital was obtained by dividing the total depreciation of the banks by the total fixed assets. The price of loanable funds was computed by dividing the total interest expenses by the total loanable funds. All input and output vectors employed in this study are reported in USD million.

Table 2 presents the descriptive statistics of the input and output vectors used in this study. The study sample consists of 261 commercial banks from five countries with 1668 observations. The commercial banks had average total assets of USD54,775.01 million, with a standard deviation as high as USD146,678.75 million. Thus, the banks were relatively diverse in terms of their scale of operations. In addition, the banks' average total deposits for the period amount to USD46,535.65 million, which is USD14,947.41 million more than the average total loans given out by the commercial banks. The banks were also able to generate, on average, USD1,587.45 million in interest income compared to an average interest expense of USD651.91 million. Finally, the banks were able to 
Table 2. Descriptive statistics of input and output variables

\begin{tabular}{lccccccc}
\hline & Total Assets & Deposits & Loans & Investment & $\begin{array}{c}\text { Interest } \\
\text { income }\end{array}$ & $\begin{array}{c}\text { Interest } \\
\text { expenses }\end{array}$ & $\begin{array}{c}\text { Pre-tax } \\
\text { profit }\end{array}$ \\
\hline Mean & & \multicolumn{7}{c}{ In Million USD } \\
Standard Deviation & 146678.75 & 128508.91 & 78246.50 & 63156.68 & 4516.38 & 1935.31 & 1620.45 \\
Minimum & 3.44 & 0.70 & -18.38 & 0.00 & 0.06 & 0.00 & -13601.38 \\
Maximum & 1414079.13 & 1286242.61 & 683890.72 & 733634.35 & 63863.19 & 25730.00 & 23788.55 \\
Count & 1668 & 1668 & 1668 & 1668 & 1668 & 1668 & 1668 \\
\hline
\end{tabular}

generate an average of USD302.87 million in terms of profit before taxes, although some of the banks did experience losses as high as USD13,601.38 million.

The measure of financial market regulations used in this study consists of bank ownership, foreign bank competition, private sector credit and interest rate control. These dimensions were first formulated by Gwartney et al. (2011) to measure the credit situation of a particular country. A high index indicates that banks are free from government control, and hence higher bank efficiency is expected. As highlighted by Claessens and Klingebiel (2001), Barth et al. (2004) and Barth et al. (2010), banks are able to exploit economies of scale and scope that contribute to higher efficiency levels when they are not subjected to government control.

Ownership of banks was computed based on the percentage of bank deposits held by the privately owned banks. A high index of bank ownership indicates that the country has a larger percentage of deposits held by privately owned banks rather than stateowned banks. Therefore, the country is dominated by privately owned banks rather than state-owned banks. Because decision making in privately owned banks is more independent than in state-owned institutions, we expect higher bank efficiency levels if the country's commercial bank deposits are largely held by privately owned banks.

However, the foreign bank competition index helps to capture foreign banking activities in the region. This index is calculated based on approved foreign bank applications as well as the foreign banking assets in the country's banking sector. Banks are expected to per- form better in terms of cost control and profit generation under a competitive environment because foreign bank participation in the banking system contributes to higher contestability of the banking sector, which leads to healthy competition (Claessens \& Laeven, 2004). In addition, Clarke et al. (2000) and Claessens, Demirgüc-Kunt, \& Huizinga, (2001) also suggested that higher foreign bank penetration contributes to higher bank efficiency level by inducing healthy competition in the banking system.

Next, private sector credit provides a measure of the extent of government borrowing relative to privatesector borrowing with the banks. According to Gwartney et al. (2011), higher borrowings by the government indicate more central planning wherein the commercial banks are largely controlled by the government, hence resulting in more policy planning rather than profit-maximization decisions. Higher ratings were assigned to countries where private-sector borrowings dominated the markets. In such cases, we expect a positive relationship between private sector credit with bank efficiency level because less policy lending and government control would result in more efficient allocations of resources. Demirgüç-Kunt et al. (2004) highlighted that banking systems dominated by state banks are more prone to restrictions in their banking activities, which may affect decisions regarding allocation of resources. This reasoning is supported by Beck, Demirgüç-Kunt and Levine (2006), who suggested that a higher degree of freedom helps stimulate efficiency by enabling banks to better diversify their activities without any restrictions by the government. 

Table 3. Average cost and profit efficiency scores for commercial banks in East Asian from 2001 to 2008

\begin{tabular}{lcccccc}
\hline $\begin{array}{l}\text { Summary } \\
\text { Statistics }\end{array}$ & Mean & $\begin{array}{c}\text { Standard } \\
\text { Deviation }\end{array}$ & Minimum & Maximum & Count \\
\hline \multirow{2}{*}{ China } & Cost & 0.437 & 0.256 & 0.041 & 1.000 & 194 \\
& profit & 0.619 & 0.433 & 0.190 & 1.000 & 194 \\
Hong Kong & Cost & 0.280 & 0.193 & 0.008 & 1.000 & 196 \\
& profit & 0.446 & 0.293 & -0.033 & 1.000 & 196 \\
Japan & Cost & 0.219 & 0.189 & 0.011 & 1.000 & 706 \\
& profit & 0.761 & 0.170 & 0.250 & 1.000 & 706 \\
Korea & Cost & 0.254 & 0.109 & 0.092 & 0.582 & 105 \\
& profit & 0.363 & 0.096 & 0.187 & 0.584 & 105 \\
Taiwan & Cost & 0.261 & 0.135 & 0.060 & 1.000 & 264 \\
& profit & 0.414 & 0.124 & 0.146 & 1.000 & 264 \\
\hline
\end{tabular}

ing implies that to maximize profit, bank management could further reduce their input mix by another $23.9 \%$ with the same level of outputs.

After the efficiency scores were estimated, the unbalanced panel data from a Tobit regression were estimated to determine the effects of credit market regulations and country governance on both the cost and profit efficiencies of commercial banks in the East Asian countries. The Hausman test was used to determine the choice between random- and fixedeffect models. The null hypothesis for the Hausman test states that the individual effects are uncorrelated with the regressors in the estimated model (Hausman, 1978). A high value of the Hausman test statistic favors a fixed-effect model as opposed to a random-effect model, which will result in biased estimators. The reported Hausman statistics for cost and profit efficiency estimation are 39.72 and 45.02, respectively, which indicate that the null hypothesis can be rejected for both models. Hence, the fixed-effect estimation is preferred over the random-effect model.

The Tobit regression estimates are presented in Table 4 . The results show that the cost efficiency level of commercial banks in the East Asian countries is more sensitive to country governance. Similarly, the profit efficiency level of the commercial banks in the region is affected by both financial market regulations and country governance.
Next, greater freedom in interest rate regulation was found to be positively related to cost efficiency but negatively related to the profit efficiency level of commercial banks in the region. This result indicates that in countries with more freedom to set their interest rates based on market forces, stable monetary policy, and positive real deposit and lending rates, the banks are more cost efficient. However, the negative relationship between profit efficiency and interest rate regulations might indicate that banks tend to offer better pricing to markets to attract more loans and deposits by earning less profit. This behavior justifies a more competitive market where banks fail to extract economic rent to gain higher profits from the markets. In addition, greater financial freedom may hurt profit efficiency because banks tend to engage in higher risk-taking activities, which might contribute to losses in the capital market, resulting in lower earnings (González, 2005). This reasoning is consistent with the findings reported by Sufian and Habibullah (2010), who found that monetary freedom hurts banks' profitability, which indicates the important roles played by governments in developing countries in controlling monetary policies. This finding is also consistent with the studies of Delis et al. (2009) and Beltratti and Stulz (2009).

Political stability and regulatory quality tend to have a negative impact on bank efficiency, which suggests that in a more mature and advanced economy 
Table 4. Tobit regression estimates of cost and profit efficiency

\begin{tabular}{|c|c|c|c|c|}
\hline \multirow[b]{2}{*}{ Variable } & \multicolumn{2}{|c|}{ Model 1} & \multicolumn{2}{|c|}{ Model 2} \\
\hline & Cost efficiency & Profit efficiency & Cost efficiency & Profit efficiency \\
\hline & -0.077 & -1.529 & -0.077 & -1.529 \\
\hline \multirow[t]{3}{*}{ Constant } & $(0.268)$ & $(0.487)$ & $(0.213)$ & $(0.374)$ \\
\hline & {$[-0.29]$} & {$[-3.14]^{* * *}$} & {$[-0.362]$} & {$[-4.088]^{* * *}$} \\
\hline & 0.007 & -0.006 & 0.007 & -0.006 \\
\hline \multirow[t]{3}{*}{ Bank Size } & $(0.014)$ & $(0.022)$ & $(0.016)$ & $(0.024)$ \\
\hline & {$[0.518]$} & {$[-0.294]$} & {$[0.438]$} & {$[-0.250]$} \\
\hline & -0.007 & 0.000 & -0.007 & 0.000 \\
\hline \multirow[t]{3}{*}{ Ownership of banks } & $(0.007)$ & $(0.011)$ & $(0.006)$ & $(0.012)$ \\
\hline & {$[-0.949]$} & {$[0.028]$} & {$[-1.167]$} & {$[0.030]$} \\
\hline & 0.001 & 0.020 & 0.001 & 0.020 \\
\hline \multirow[t]{3}{*}{ Competition in domestic banking } & $(0.006)$ & $(0.009)$ & $(0.006)$ & $(0.007)$ \\
\hline & {$[0.164]$} & {$[2.088]^{* *}$} & {$[0.164]$} & {$[2.857]^{* * *}$} \\
\hline & 0.037 & -0.085 & 0.037 & -0.085 \\
\hline \multirow[t]{3}{*}{ Interest rate regulations } & $(0.018)$ & $(0.029)$ & $(0.010)$ & $(0.020)$ \\
\hline & {$[2.030]^{* *}$} & {$[-2.928]^{* * *}$} & {$[3.700]^{* *}$} & {$[-4.250]^{* * *}$} \\
\hline & -0.005 & -0.028 & -0.005 & -0.028 \\
\hline \multirow[t]{3}{*}{ Credit market regulation } & $(0.020)$ & $(0.032)$ & $(0.020)$ & $(0.031)$ \\
\hline & {$[-0.253]$} & {$[-0.873]$} & {$[-0.253]$} & {$[-0.903]$} \\
\hline & -0.023 & -0.090 & -0.023 & -0.090 \\
\hline \multirow[t]{3}{*}{ Political stability } & $(0.014)$ & $(0.022)$ & $(0.022)$ & (0.019) \\
\hline & {$[-1.641]$} & {$[-4.005]^{* * *}$} & {$[-1.045]$} & {$[-4.737]^{* * *}$} \\
\hline & 0.136 & 0.230 & 0.136 & 0.230 \\
\hline \multirow[t]{3}{*}{ Government effectiveness } & $(0.042)$ & $(0.068)$ & $(0.054)$ & (0.058) \\
\hline & {$[3.200]^{* * *}$} & {$[3.399]^{* * *}$} & {$[2.519]^{* *}$} & {$[3.966]^{* * *}$} \\
\hline & -0.297 & -0.235 & -0.297 & -0.235 \\
\hline \multirow[t]{3}{*}{ Regulatory quality } & $(0.029)$ & $(0.047)$ & $(0.038)$ & $(0.033)$ \\
\hline & {$[-10.102]^{* * *}$} & {$[-5.001]^{* * *}$} & {$[-7.816]^{* * *}$} & {$[-7.121]^{* * *}$} \\
\hline & 0.152 & 0.179 & 0.152 & 0.179 \\
\hline \multirow[t]{2}{*}{ Control of corruption } & $(0.044)$ & $(0.071)$ & $(0.058)$ & $(0.072)$ \\
\hline & {$[3.413]^{* * *}$} & {$[2.529]^{* *}$} & {$[2.621]^{* * *}$} & {$[2.486]^{* *}$} \\
\hline Siama & 0.174 & 0.285 & 0.174 & 0.285 \\
\hline sigma & $(0.003)$ & $(0.007)$ & $(0.005)$ & $(0.001)$ \\
\hline LR Chi2 (9) & $314.17^{* * *}$ & $458.33^{* * *}$ & $224.32^{* * *}$ & 487.41 \\
\hline \multirow[t]{2}{*}{ Pseudo R2 } & 0.162 & 0.287 & 0.162 & 0.287 \\
\hline & 0.104 & 0.166 & 0.104 & 0.166 \\
\hline \multirow[t]{2}{*}{ Standard deviation } & $(0.002)$ & $(0.003)$ & $(0.002)$ & $(0.003)$ \\
\hline & {$[54.129]^{* * *}$} & {$[54.107]^{* * *}$} & {$[54.129]^{* * *}$} & {$[54.107]^{* * *}$} \\
\hline Log likelihood function & 292.289 & 569.497 & 292.289 & 569.497 \\
\hline
\end{tabular}

This table provides the Tobit regression estimation corrected for robust standard errors (Model 1) and a bootstrap-based model (Model 2) for East Asian commercial banks from 2001 to 2008.

Notes: ${ }^{* *}$ and ${ }^{* *}$ denote significance at the $1 \%$ and $5 \%$ levels, respectively. Standard errors are shown in parentheses, and test statistics are reported in brackets. 
with higher income levels, banks incur higher costs of financing because of higher personnel and capital expenses (Dietsch \& Lozano-Vivas, 2000). Moreover, banks in more developed and mature markets tend to be less efficient in controlling their expenditures because they focus more on business expansion. Banks may also become complacent in controlling their operation in a more stable economy, which might lead to the "quiet life" hypothesis introduced by Berger and Hannan (1998). The result is supported by Engerman and Sokoloff (1997), Acemoglu et al., (2001) and William and Levine (2003), who found better institutional environments resulted in lower bank earnings.

Findings have also shown that government effectiveness is positively related to bank efficiency. A country that is characterized by political independence and an efficient government has a more efficient banking sector. The results are supported by Levine, Loayza and Beck (2003), who found that a better institutional environment facilitates greater market and financial development, which lead to higher efficiency of the banking industry. In a similar vein, Lensink and Meesters (2007), in their analysis of institutions and bank performance, found that government effectiveness reduces banks' costs in dealing with bureaucracy. The result is consistent with the work of Chen (2009), who found that government effectiveness resulted in the high cost efficiency of Sub-Saharan African banks. Barth et al. (2010) also reported that greater government effectiveness indicated higher institutional quality, which eventually contributed to higher bank efficiency.

The results also show that the ability to control for corruption is positively related to bank efficiency level, demonstrating that the lower the incidence of corruption is, the lower the costs of bribing become and hence the higher the bank efficiency level becomes (Lensink and Meesters, 2007). In addition, corruption may also negatively affect the degree of market competitiveness and lead to inefficient loan offerings (Boudriga, Taktak, \& Jellouli, 2009). The result is also consistent with the work of Sufian and Habibullah (2010), who found that freedom of corruption was positively related to banks' profitability in Malaysia.

In general, our results suggest that for any country, the ability to control corruption, improve government effectiveness and institute less stringent regulatory conditions will have positive effects on bank efficiency.

\section{Conclusion}

This study examined the effects of financial market regulations and country governance on bank efficiency in East Asian countries. The study period was chosen to span from 2001 to 2008 to reflect the impact of current financial market regulations and country governance on bank efficiency. Non-parametric Data Envelopment Analysis (DEA) was employed to obtain cost and profit efficiency scores. A Tobit unbalanced panel data regression was then estimated to analyze the impact of banking regulations and country governance on bank efficiency.

The results show that commercial banks in the East Asian region are relatively more profit efficient than they are cost efficient. The Tobit regression estimation result indicates that the cost efficiency of commercial banks in East Asia is more sensitive to country governance, whereas profit efficiency is affected by both financial market regulations and country governance.

Greater freedom in setting interest rates was found to be positively correlated with cost-efficiency level, suggesting that countries with more financial freedom and independence are more cost efficient. The result is consistent with the work of González (2005), Delis et al. (2009) and Beltratti and Stulz (2009) and Sufian and Habibullah (2010). Furthermore, the results show that government effectiveness is positively related to bank efficiency, again demonstrating that countries with more freedom have more efficient banking systems. The result is consistent with the studies of Levine et al. (2003), Lensink and Meesters (2007), Chen (2009) and Barth et al. (2010).

However, the results show that political stability and regulatory quality are negatively related to bank efficiency levels. The results are consistent with the work of Engerman and Sokoloff (1997), Acemoglu et al., (2001) and William and Levine (2003). Consistent with economic theory, the ability to control for corruption is positively related to bank efficiency level; supporting the views of Lensink and Meesters (2007), Boudriga et al. (2009) and Sufian and Habibullah (2010).

The sample examined herein may be a limitation of this study because it only focuses on commercial banks in East Asian countries. Therefore, future studies may consider extending the study to other Asian countries and comparing the differences in institutional framework among different Asian regions to develop a better 
economic picture that can be generalized to the entire Asian region. Overall, to create more efficient banks, the results of our study suggest that countries should allow the market determine interest rates with less stringent regulatory conditions.

\section{References}

Acemoglu, D, Johnson, S., \& Robinson, J. A. (2001). The colonial origins of comparative development: An empirical investigation. American Economic Review, 91 (5), 1369-1401.

Al-Obaidan, A.M. (2009). Monetary stability and performance in the commercial banking industry of emerging markets. International Research Journal of Finance and Economics, 26, 60-72.

Amemiya, T. (1973). Regression analysis when the dependent variable is a truncated normal. Econometrica, 41 (6), 997-1016.

Asaftei, G., \& Kumbhakar, S. (2008). Regulation and efficiency in transition: The case of Romanian banks. Journal of Regulatory Economics, 33 (3), 253-282.

Barth, J. R., Brunmgaugh, D.R., \& Wilcox, J.A. (2000). The repeal of Glass-Steagall and the advent of broad banking. Journal of Economic Perspective, 14 (2), 191-204.

Barth, J. R., Caprio, G., \& Levine, R, (2004). Bank regulation and supervision: What works best? Journal of Financial Intermediation, 13 (2), 205-248.

Barth, J. R., Chen, L., Yue, M., Seade, J., \& Song, F. M. (2010). Do bank regulation, supervision and monitoring enhance or impede bank efficiency? Available at, http://ssrn.com/abstract $=1579352$

Beck, T., Demirgüç-Kunt, A., \& Levine, R. (2003). Law, endowments, and finance. Journal of Financial Economics, 70 (2), 137-181.

Beck, T., Demirgüç-Kunt, A., \& Levine, R. (2006). Bank concentration, competition, and crises: First results. Journal of Banking and Finance, 30 (5), 1581-1603.

Beck, T., Demirgüç-Kunt, A., Levine, R., \& Maksimovic, V. (2001). Financial structure and economic Development: Firm, industry and country evidence. In A. Demirgüç-Kunt, \& R. Levine (Eds.), Financial structure and economic growth: A cross-country comparison of banks, markets and development (pp. 202-242). Cambridge, MA: The MIT Press.
Beltratti, A., \& Stulz, R. M. (2009). Why did some banks perform better during the credit crisis? A crosscountry study of the impact of governance and regulation (Working Paper No. 15180). National Bureau of Economic Research.

Berger, A. N., \& Hannan, T. H. (1998). The efficiency cost of market power in the banking industry: A test of the "Quiet Life" and related hypotheses. Review of Economics and Statistics, 80 (3), 454465.

Berger, A. N., \& Humphrey, D. B. (1992). Measurement of efficiency issues in commercial banking. In A. N. Berger \& D. B. Humphrey (Eds.), Output measurement in the service sectors (pp. 245-300). Chicago, IL: University of Chicago Press.

Berger, A. N., \& Mester, L. J. (1997). Inside the black box: What explains differences in the efficiencies of financial institutions. Journal of Banking and Finance, 21 (7), 895-947.

Besley, T., \& Burgess, R. (2004). Can labor regulation hinder economic performance? Evidence from India. Quarterly Journal of Economics, 119 (1), 91-134.

Borovicka, J. (2007). Banking efficiency and foreign ownership in transition: Is there evidence of a cream-skimming effect? Financial Stability Report $13,68-82$

Boudriga, A., Taktak, N. B., \& Jellouli, S. (2009). Banking supervision and nonperforming loans: A cross-country analysis. Journal of Financial Economic Policy, 1 (4), 286-318.

Chan, S. G., \& Karim, M. Z. A. (2010). Bank efficiency and macro-economic factors: The case of developing countries. Global Economic Review, 39 (3), 269-289.

Charnes, A., Cooper, W. W., \& Rhodes, E. (1978). Measuring the efficiency of decision making units. European Journal of Operational Research, 2 (6), 429-444.

Chen, C. (2009) Bank efficiency in Sub-Saharan African Middle-Income Countries (Working Paper No. 09/14). International Monetary Fund.

Chen, T. Y., \& Yeh, T. L. (2000). A measurement of bank efficiency, ownership and productivity changes in Taiwan. Service Industry Journal, 20 (1), 95-109.

Chortareas, G. E., Girardone, C., \& Ventouri, A. (2013). Financial freedom and bank efficiency: Evidence from the European Union. Journal of Banking and Finance, 37 (4), 1223-1231. 
Claessens, S., Demirgüc-Kunt, A., \& Huizinga, H. (2001). How does foreign entry affect domestic banking markets. Journal of Banking and Finance, 25 (5), 891-911.

Claessens, S., \& Klingebie, D. (2001). Competition and scope of activities in financial services. World Bank Research Observer, 16 (1), 19-40.

Claessens, S., \& Laeven, L. (2004). What drives bank competition? Some international evidence. Journal of Money, Credit, and Banking, 36 (3), 563-583.

Clarke, F., Cull, R., Amato, L., \& Molinari, A. (2000). On the kindness of strangers? The impact of foreign entry on domestic banks in Argentina" In S. Claessen, M. Jansen (Ed.), The internationalization of financial services: issues and lessons for developing countries (pp.331-354). London, UK: Kluwer Law International.

Delis, M. D., Molyneux, P., \& Pasiouras, F. (2009). Regulations and productivity growth in banking (MPRA Working Paper No. 13891). University Library of Munich, Germany.

Demirgüc-Kunt, A., Laeven, L., \& Levine, R. (2004). Regulations, market structure, institutions, and the cost of financial intermediation. Journal of Money, Credit, and Banking, 36 (3), 593-622.

Dietsch, M., \& Lozano-Vivas, A. (2000). How the environment determines banking efficiency: A comparison between French and Spanish industries. Journal of Banking and Finance, 24 (6), 985-1004.

Engerman, S. L., \& Sokoloff, K. L. (1997). Factor endowments, institutions, and differential paths of growth among new world economies: A view from economic historians of the United States. In S. Haber (Ed.), How Latin America fell behind. Essays on the Economic History of Brazil and México, 1800-1914 (pp. 260-304). Stanford, CA: Stanford University Press.

Evanoff, D. D. (1998). Assessing the impact of regulation on bank cost efficiency. Economic Perspective, $22(2), 21-32$

Farrell, M. J. (1957). The measurement of productivity efficiency. Journal of the Royal Statistical Society, 120 (3), 253-290.

Giannone, D. Lenza, M., \& Reichlin, L. (2010). Market freedom and the global recession. International Monetary Fund Economic Review, 59 (1), 111-135.

González, F. (2005). Bank regulation and risk-taking incentives: An international comparison of bank risk. Journal of Banking and Finance, 29 (5), 1153-1184.
González, F. (2009). Determinants of bank-market structure: Efficiency and political economy variables. Journal of Money, Credit, and Banking, 41 (06), 735-754.

Gwartney, J., Lawson, R., Hall, J. (2011). Economic Freedom of the World: 2011 Annual Report. Vancouver, BC: Fraser Institute. Retrieved from http://www.freetheworld.com/2011/reports/ world/EFW2011_complete.pdf

Hausman, J. A. (1978). Specification tests in econometrics. Econometrica, 46 (6), 1251-1271.

Humphrey, D. B., \& Pulley, L. B. (1997). Banks' responses to deregulation: Profits, technology, and efficiency. Journal of Money, Credit, and Banking, 29 (1), 73-93.

Isik, I., \& Hassan, M. K. (2003). Efficiency, ownership and market structure, corporate control and governance in the Turkish banking industry. Journal of Banking and Finance, 30 (9-10), 1363-1421.

Jappelli, T., \& Pagano, M. (2002). Information sharing, lending and defaults: Cross countries evidence. Journal of Banking and Finance, 26 (10), 2017 2045.

Johnson, S., Kaufmann, D., \& Shleifer, A. (1997). The unofficial economy in transition. Brookings Paper on Economic Activity, 2, 159-239.

Kalish, L., \& Gilbert, R. A. (1973). The influence of bank regulation on the operating efficiency of commercial banks. Journal of Finance, 28 (5), 1287-1301.

Kaufmann, D., Kraay, A., \& Mastruzzi, M. (2009). Governance matters VIII: aggregate and individual governance indicators 1996-2008. Policy (Research Working Paper No. 4978). The World Bank.

La Porta, R., Lopez-de-Silanes, F., Shleifer, A., \& Vishney, R.W. (1998). Law and finance. Journal of Political Economy, 106 (6), 1113-1155.

Lensink, R., \& Meesters, A. (2007). Institutions and bank performance: A stochastic frontier analysis. Available at, http://ssrn.com/abstract $=965825$

Lensink, R, Meesters, A., \& Naaborg, I. (2008). Bank efficiency and foreign ownership: Do good institutions matter? Journal of Banking and Finance, 32 (5), 834-844.

Levine, R., Loayza, N., \& Beck T (2003). Financial intermediation and growth: Causality and causes. Journal of Monetary Economics, 46 (1), 31-77. 
Miller, T., \& Holmes, K. R., Kim, A. B., Markheim, D., Roberts, J. M., \& Walsh, C. (2010). Index of Economic Freedom. Washington, DC: The Heritage Foundation and Dow Jones \& Company, Inc.

Mishkin, F. S. (2000). Prudential supervision: Why is it important and what are the issues (Working Paper No. 7926). National Bureau of Economic Research. Retrieved from http://www.nber.org/ papers/w7926.pdf

Nabi, M. S., \& Suliman, M. O. (2008). The institutional environment and the banking-growth nexus: Theory and investigation for MENA (MPRA Working Paper No. 11854). University Library of Munich, Germany.

Pasiouras, F. (2008). International evidence on the impact of regulations and supervision on banks' technical efficiency: An application of two-stage data envelopment analysis. Review of Quantitative Finance and Accounting, 30 (2), 187-223.

Stigler, G. J. (1971). The theory of economic regulation. Bell Journal of Economic Management Science, 2 (1), 3-21.

Sufian, F., \& Habibullah, M. S. (2010). Developments in the efficiency of the Thailand banking sector: A DEA approach. International Journal of Development Issues, 9 (3), 226-245.

Sufian, F., \& Habibullah, M.S. (2010). Does economic freedom fosters banks' performance? Panel evidence from Malaysia. Journal of Contemporary Accounting and Economics, 6 (2), 77-91.

Tobin, J. (1958). Estimation of relationships for limited dependent variables. Econometrica, 26 (1), 24-36.

William, E., \& Levine, R. (2003). Tropics, germs, and crops: How endowments influence economic development. Journal of Monetary Economics, 50 (1), 3-40.

\section{Acknowledgements}

This study is part of the research supported by UMRG research grant (RP001C-13SBS), University of Malaya 
